\title{
Influence of pretreatment conditions on low-temperature carbon monoxide oxidation over $\mathrm{CeO}_{2} / \mathrm{Co}_{3} \mathrm{O}_{4}$ catalysts
}

\author{
Chih-Wei Tang ${ }^{\mathrm{a}, \mathrm{b}}$, Chao-Chieh Kuo ${ }^{\mathrm{a}, \mathrm{b}}$, Ming-Chih Kuo ${ }^{\mathrm{b}}$, \\ Chen-Bin Wang ${ }^{\mathrm{a}, *}$, Shu-Hua Chien ${ }^{\mathrm{b}, \mathrm{c}, * *}$ \\ ${ }^{a}$ Department of Applied Chemistry, Chung Cheng Institute of Technology, National Defense University, Tahsi, Taoyuan 33509, Taiwan, ROC \\ ${ }^{\mathrm{b}}$ Institute of Chemistry, Academia Sinica, Taipei 11529, Taiwan, ROC \\ ${ }^{c}$ Department of Chemistry, National Taiwan University, Taipei 10764, Taiwan, ROC
}

Received 19 September 2005; received in revised form 8 April 2006; accepted 12 April 2006

Available online 12 June 2006

\begin{abstract}
The modification of ceria $\left(\mathrm{CeO}_{2}\right)$ on high surface area cobaltic oxide $\left(\mathrm{Co}_{3} \mathrm{O}_{4}\right)$ and the promotion effect of $\mathrm{CO}$ oxidation via different pretreatment conditions were studied. The high-valence cobalt oxide was prepared first by precipitation-oxidation in ice bath, followed by reduction at $230{ }^{\circ} \mathrm{C}$ to get pure and high surface area cobaltic oxide (assigned as R230, $S_{\mathrm{BET}}=100 \mathrm{~m}^{2} \mathrm{~g}^{-1}$ ). Further, the Ce20/R230 catalyst was prepared by impregnation with cerium nitrate ( $20 \%$ cerium loading). Pretreatment of Ce20/R230 catalyst was divided into two methods: reduction (under 200 and $400{ }^{\circ} \mathrm{C}$ ) and calcination (under 350 and $550{ }^{\circ} \mathrm{C}$ ). The catalysts were characterized by X-ray diffraction (XRD), infrared (IR), and diffuse reflectance spectroscopy (DRS), and temperature-programmed reduction (TPR) and by nitrogen adsorption at $-196{ }^{\circ} \mathrm{C}$. The results showed that pretreatment under low-temperatures obtained both larger surface area and better activity. The Ce20/R230-H200 catalyst exhibited the highest surface area $\left(S_{\mathrm{BET}}=109 \mathrm{~m}^{2} \mathrm{~g}^{-1}\right)$ and the best catalytic activity in CO oxidation with $\mathrm{T}_{50}(50 \%$ conversion $)$ at $88{ }^{\circ} \mathrm{C}$ among series of catalysts due to the combined effect of cobaltic oxide and ceria. The optimized pretreatment of $\mathrm{CeO}_{2} / \mathrm{Co}_{3} \mathrm{O}_{4}$ catalysts can clearly enhance the catalytic activity. (C) 2006 Elsevier B.V. All rights reserved.
\end{abstract}

Keywords: Cobaltic oxide; Ceria; CO oxidation

\section{Introduction}

Low-temperature abatement of carbon monoxide is important in environmental pollution control [1]. There are several reports describing the use of noble metals for $\mathrm{CO}$ oxidation at ambient temperatures [2-6]. However, the high cost of noble metals and their sensitivity to sulfur poisoning have stimulated the search for substitute catalysts. Because of the price and the limited availability of previous metals, considerable attention has been paid to various transition metal oxides and mixed metal oxides [7-12]. Among these metal oxides, cobaltic oxide $\left(\mathrm{Co}_{3} \mathrm{O}_{4}\right)$ is very attractive for the preparation of oxidation catalysts because of the presence of mobile oxygen in $\mathrm{Co}_{3} \mathrm{O}_{4}$ [8-13]. The high activity of $\mathrm{Co}_{3} \mathrm{O}_{4}$ on $\mathrm{CO}$ oxidation is likely to

\footnotetext{
* Corresponding author. Tel.: +886 227898529 .

** Corresponding author. Fax: +886 33891519

E-mail addresses: chenbin@ccit.edu.tw (C.-B. Wang), chiensh@gate.sinica.edu.tw (S.-H. Chien).
}

be due to the relatively low $\Delta H$ of vaporization of $\mathrm{O}_{2}[14,15]$. This means that the $\mathrm{Co}-\mathrm{O}$ bond strength of $\mathrm{Co}_{3} \mathrm{O}_{4}$ is relatively weak, so easily reactive oxygen can be obtained from the lattice oxygen. Thus, many researchers have measured the catalytic activity of $\mathrm{Co}_{3} \mathrm{O}_{4}$ for $\mathrm{CO}$ oxidation [8-13,16].

Ceria has a high oxygen storage capacity and well-known catalytic and redox properties (couples of $\mathrm{Ce}^{4+} / \mathrm{Ce}^{3+}$ ), making more oxygen available for the oxidation process [17]. The most important property is the oxygen storage and releasing capacity of $\mathrm{CeO}_{2}$ [18-22]. It improves $\mathrm{CO}$ oxidation and $\mathrm{NO}_{x}$ reduction. As is also well known, $\mathrm{CeO}_{2}$ is a promoter additive [23-25]. The rapid growth in the applications and the characterization of $\mathrm{CeO}_{2}$-containing catalysts has been documented [26-32]. In particular, the $\mathrm{CuO} / \mathrm{CeO}_{2}$ catalyst was reported to be very active for the complete $\mathrm{CO}$ oxidation and even comparable to noble metals [26]. Good catalytic activity is also observed for $\mathrm{CoO}_{x} /$ $\mathrm{CeO}_{2}$ composite catalysts [30], for which the $T_{50}(50 \%$ conversion) approaches $125^{\circ} \mathrm{C}$. However, finding strategies to improve and control redox properties in preparation process to raise the catalytic activity is still a fundamental challenge. 
In a previous work, we have demonstrated that the activity of $\mathrm{Co}_{3} \mathrm{O}_{4}$ toward $\mathrm{CO}$ oxidation is enhanced significantly by increasing the surface area $\left(S_{\mathrm{BET}}\right)$ [12]. For this reason the present work has been devoted to study the effect of ceria on the high surface area cobaltic oxide. The study object of this work is to understand the correlations between the effects of pretreatment conditions on the $\mathrm{CeO}_{2} / \mathrm{Co}_{3} \mathrm{O}_{4}$ catalysts and the catalytic properties for $\mathrm{CO}$ oxidation. The characteristics of catalysts are determined by means of X-ray diffraction (XRD), infrared (IR), and diffuse reflectance spectroscopy (DRS), and by nitrogen adsorption at $-196{ }^{\circ} \mathrm{C}$ and temperature-programmed reduction (TPR). The catalytic activities for $\mathrm{CO}$ oxidation of $\mathrm{CeO}_{2} / \mathrm{Co}_{3} \mathrm{O}_{4}$ catalysts are also compared.

\section{Experimental}

\subsection{Catalyst preparation}

The high-valence cobalt oxide (marked as $\mathrm{CoO}_{x}$ ) was synthesized first by the precipitation-oxidation method in an aqueous solution. The detailed preparation procedure was described in a previous paper [10]. Furthermore, the pure cobaltic oxide $\left(\mathrm{Co}_{3} \mathrm{O}_{4}\right)$ was refined from $\mathrm{CoO}_{x}$ by a controlled hydrogen reduction in a temperature-programmed reduction system to $230{ }^{\circ} \mathrm{C}$ (assigned as R230).

The $\mathrm{CeO}_{2} / \mathrm{Co}_{3} \mathrm{O}_{4}$ catalyst was prepared by impregnation of the $\mathrm{Co}_{3} \mathrm{O}_{4}$ support with an aqueous solution of the desired concentration of $\mathrm{Ce}\left(\mathrm{NO}_{3}\right)_{3} \cdot 6 \mathrm{H}_{2} \mathrm{O}$ (Aldrich, the ceria loading is $20 \mathrm{wt} . \%$ and assigned as Ce20/R230). The catalyst was dried at $110{ }^{\circ} \mathrm{C}$ for $24 \mathrm{~h}$, followed by two pretreatment methods: reduction in an $\mathrm{H}_{2}$ stream (under 200 and $400{ }^{\circ} \mathrm{C}$, assigned as Ce20/R230-H200 and Ce20/R230-H400) for $2 \mathrm{~h}$ and calcination in an air stream (under 350 and $550{ }^{\circ} \mathrm{C}$, assigned as $\mathrm{Ce} 20 /$ R230-C350 and Ce20/R230-C550) for $4 \mathrm{~h}$.

\subsection{Catalyst characterization}

X-ray diffraction (XRD) measurements were performed using a Siemens D5000 diffractometer with $\mathrm{Cu} \mathrm{K}_{\alpha 1}$ radiation $(\lambda=1.5405 \AA$ ) at $40 \mathrm{kV}$ and $30 \mathrm{~mA}$ with a scanning speed in $2 \theta$ of $2^{\circ} \mathrm{min}^{-1}$. Diffraction peaks of crystalline phase were compared with those of standard compounds reported in the JCPDS data file $\left(\mathrm{Co}_{3} \mathrm{O}_{4}: 34-0394 ; \mathrm{CeO}_{2}: 09-0418\right)$. The crystallite sizes of cobaltic oxide and ceria were estimated using the Scherrer equation.

Nitrogen adsorption isotherms at $-196{ }^{\circ} \mathrm{C}$ were determined volumetrically with Micrometritics ASAP 2010. The catalysts were pre-outgassed at $5 \times 10^{-5}$ Torr for $3 \mathrm{~h}$ at $110{ }^{\circ} \mathrm{C}$. The surface area was determined from the nitrogen adsorption isotherm.

The infrared spectra were obtained with a Bomen DA-8 spectrometer in the range of $500-800 \mathrm{~cm}^{-1}$. One milligram of each powder sample was diluted with $200 \mathrm{mg}$ of vacuum-dried IR-grade $\mathrm{KBr}$ and subjected to a pressure of 8 tonnes.

The DRS spectra were measured at room temperature on a Hitachi U3410 spectrophotometer equipped with an integration sphere. The spectra were recorded against a $\mathrm{BaSO}_{4}$ standard in the region $200-800 \mathrm{~nm}$.

Reduction behavior of $\mathrm{CeO}_{2} / \mathrm{Co}_{3} \mathrm{O}_{4}$ catalysts was studied by temperature-programmed reduction (TPR). About $25 \mathrm{mg}$ of the sample was heated in a flow of $10 \% \mathrm{H}_{2} / \mathrm{He}$ gas mixture at a flow rate of $10 \mathrm{ml} \mathrm{min}^{-1}$. During TPR, the temperature was programmed to rise at $10{ }^{\circ} \mathrm{C} \mathrm{min}^{-1}$ to $550{ }^{\circ} \mathrm{C}$.

\subsection{Catalytic activity measurement}

The catalytic activity of $\mathrm{CeO}_{2} / \mathrm{Co}_{3} \mathrm{O}_{4}$ catalysts towards $\mathrm{CO}$ oxidation was carried out in a continuous flow micro-reactor. The reaction gas, a mixture of $10 \% \mathrm{O}_{2} / \mathrm{He}$ with $4 \% \mathrm{CO} / \mathrm{He}$, was fed to a $0.5 \mathrm{~g}$ catalyst at a rate of $20 \mathrm{ml} \mathrm{min}^{-1}$. Steady-state catalytic activity was measured at each temperature with the reaction temperature raised from room temperature to $200{ }^{\circ} \mathrm{C}$ in steps of $25^{\circ} \mathrm{C}$. The effluent gas was analyzed on-line using a Varian 3700 gas chromatograph with a carbosphere column. Before reaction, the catalyst was pretreated in flowing $10 \% \mathrm{O}_{2} /$ $\mathrm{He}$ at $110{ }^{\circ} \mathrm{C}$ for $1 \mathrm{~h}$ to drive away molecules pre-adsorbed from the atmosphere.

\section{Results and discussion}

\subsection{Characteristic analysis}

The phase composition and the purity are characterized by XRD. Fig. 1 shows the XRD patterns of ceria, cobaltic oxide and the Ce20/R230 catalysts. All samples except R230 (Fig. 1(b)) show a well-crystallized $\mathrm{CeO}_{2}$ phase with a fluorite-type structure. Besides the $\mathrm{CeO}_{2}$ phase, a separate crystalline $\mathrm{Co}_{3} \mathrm{O}_{4}$ (Fig. 1(c)-(e)), $\mathrm{CoO}$ (Fig. 1(e) and (f)) and $\mathrm{Co}$ (Fig. 1(f)) species are found for the Ce20/R230 catalysts. The degree of crystallinity of both phases $\left(\mathrm{Co}_{3} \mathrm{O}_{4}\right.$ and $\left.\mathrm{CeO}_{2}\right)$ increases with increasing calcined temperature (Fig. 1(c) and (d)), while the particle size is similar for samples calcined under 350 and $550{ }^{\circ} \mathrm{C}\left(\sim 7.7 \mathrm{~nm}\right.$ for $\mathrm{Co}_{3} \mathrm{O}_{4}$ and $\sim 6.0 \mathrm{~nm}$ for $\left.\mathrm{CeO}_{2}\right)$. Comparison with the results in our previous paper [12], as the cobaltic oxide calcined at $400{ }^{\circ} \mathrm{C}$, the particle size for $\mathrm{Co}_{3} \mathrm{O}_{4}$ increases from 8.2 to $15.4 \mathrm{~nm}$. Apparently, the addition of ceria shows good resistance to the sintering of cobaltic oxide under high-temperature due to the strong interaction of cobaltic oxide and ceria (the combined effect can be further characterized by TPR). Also, the degree of crystallinity of mixed phases and $\mathrm{CeO}_{2}$ increases with increasing reduction temperature (Fig. 1(e) and (f)). The particle size of $\mathrm{CeO}_{2}$ is not affected under low or high reduced temperature $(\sim 6.0 \mathrm{~nm})$, while the effect of treatment temperature under reduced atmosphere is apparent for both composition and particle size of $\mathrm{CoO}_{x}$. According to the diffraction patterns and the width of the $(200)$ diffraction pattern of crystalline $\mathrm{CoO}$, the composition of $\mathrm{CoO}_{x}$ in $\mathrm{Ce} 20 / \mathrm{R} 230$ $\mathrm{H} 200$ (Fig. 1(e)) is a mixed phase $\left[\mathrm{Co}_{3} \mathrm{O}_{4}\right.$ and $\mathrm{CoO}$, although the (3 11 1) peak of $\mathrm{Co}_{3} \mathrm{O}_{4}$ overlaps with the $\left(\begin{array}{lll}1 & 1 & 1\end{array}\right)$ peak of $\mathrm{CoO}$, the faint peak of (3 1 1) diffraction pattern can be further characterized by TPR] and the particle size of $\mathrm{CoO}$ is $6.0 \mathrm{~nm}$. As the reducing temperature increases, the composition of $\mathrm{Ce} 20 /$ R230-H400 shows $\mathrm{CoO}$ and Co mixed phases and the particle 


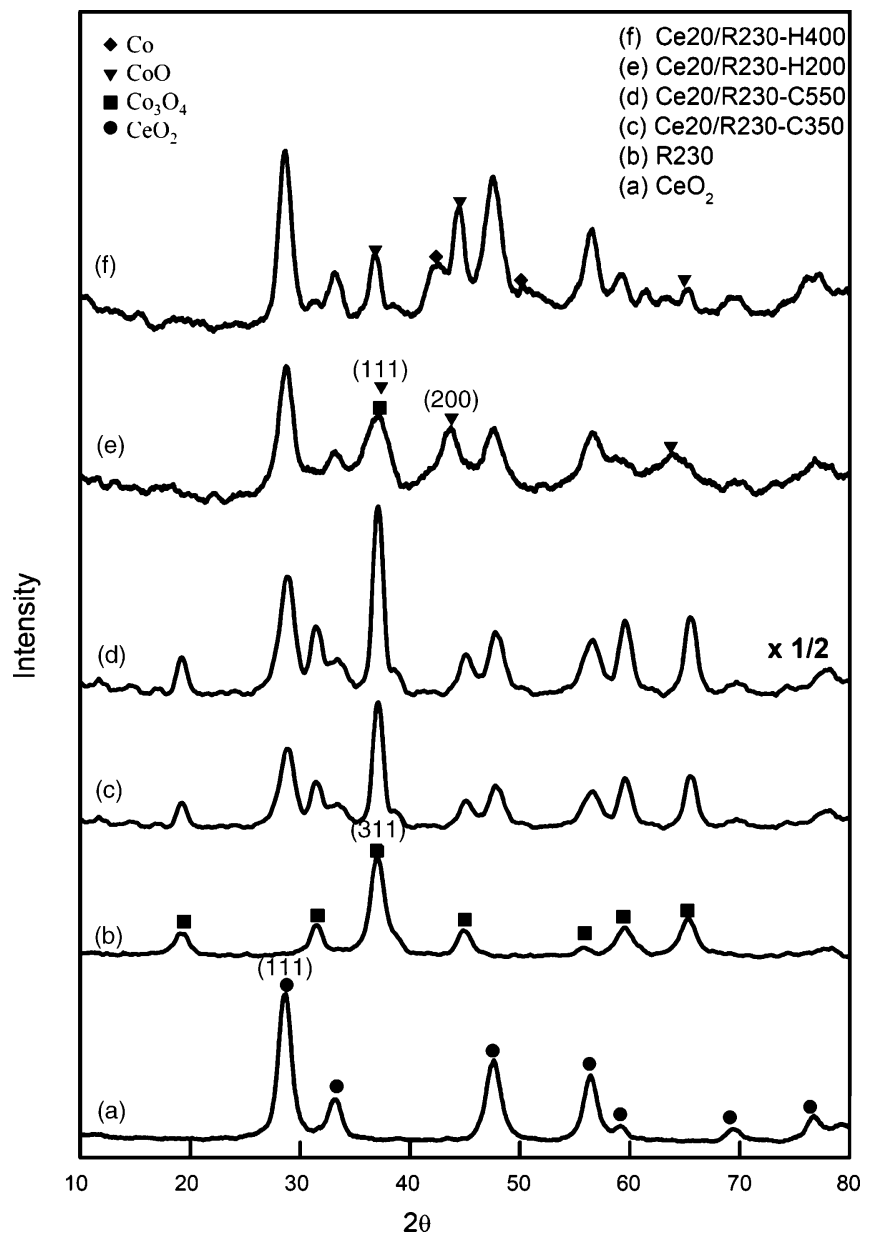

Fig. 1. XRD characterization for ceria, cobaltic oxide and the Ce20/R230 catalysts: (a) $\mathrm{CeO}_{2}$; (b) R230; (c) Ce20/R230-C350; (d) Ce20/R230-C550; (e) Ce20/R230-H200; (f) Ce20/R230-H400.

size of CoO grows to $8.3 \mathrm{~nm}$. The compositions of Ce20/R230 catalysts under different treatments are summarized in the third column of Table 1. Inspection of these results reveals that: (i) the higher the treating temperature, the sharper the diffraction peaks, indicating the degree of crystallinity is progressively growing with temperature; (ii) the slight change of particle size for $\mathrm{CoO}_{x}$ means that the introducing of ceria can resist the sintering of $\mathrm{CoO}_{x}$.

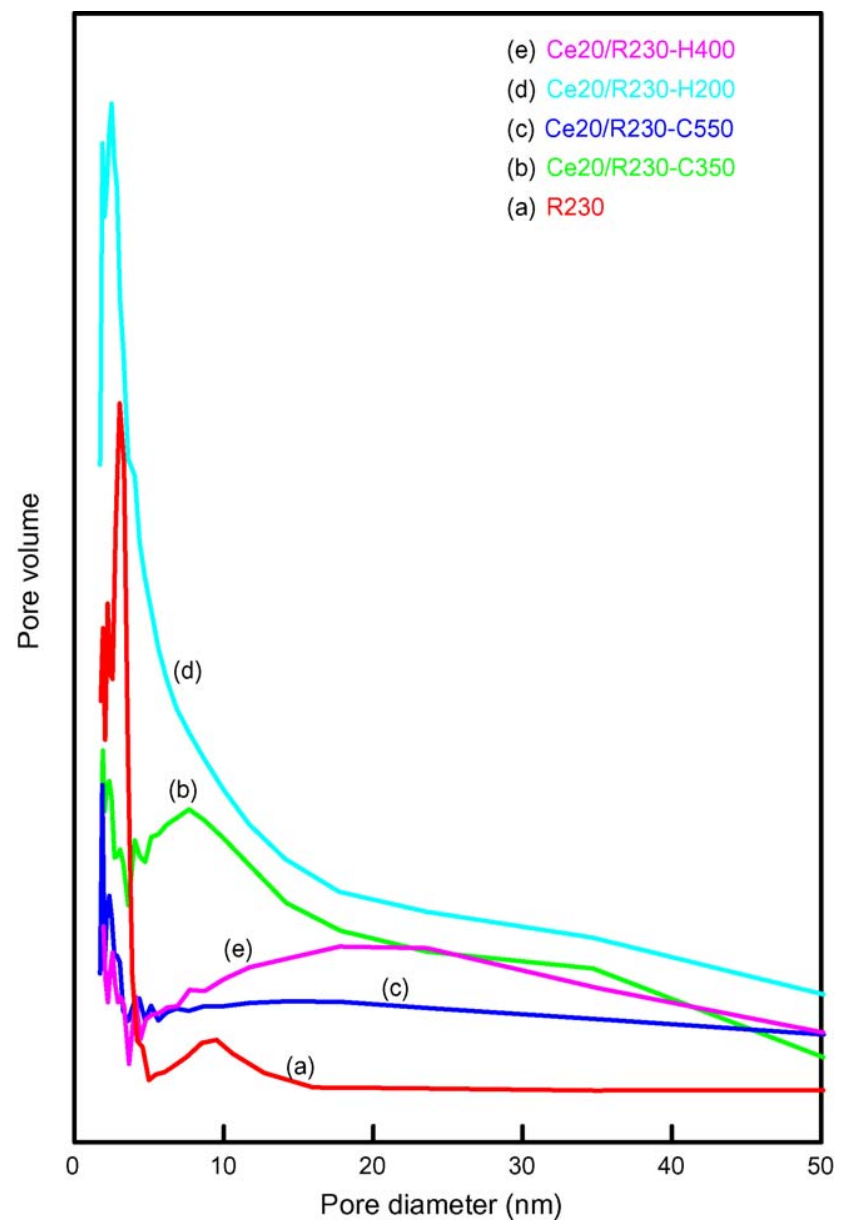

Fig. 2. Pore size distributions for Ce20/R230 catalysts: (a) R230; (b) $\mathrm{Ce} 20 /$ R230-C350; (c) Ce20/R230-C550; (d) Ce20/R230-H200; (e) Ce20/R230-H400.

The surface area $\left(S_{\mathrm{BET}}, \mathrm{m}^{2} \mathrm{~g}^{-1}\right)$ of Ce20/R230 catalysts is determined from nitrogen adsorption isotherms measured at $-196{ }^{\circ} \mathrm{C}$. The data of $S_{\mathrm{BET}}$ are given in the second column of Table 1. The results show that the optimized pretreatment can obtain high surface area of $\mathrm{CeO}_{2} / \mathrm{Co}_{3} \mathrm{O}_{4}$ catalysts. The increase in treating temperature induces a decrease in its surface area (i.e., Ce20/R230-C550 < Ce20/R230-C350; Ce20/R230$\mathrm{H} 400<\mathrm{R} 230<\mathrm{Ce} 20 / \mathrm{R} 230-\mathrm{H} 200)$. The induced decrease

Table 1

Characterization and catalytic activity for CO oxidation over Ce20/R230 catalysts

\begin{tabular}{|c|c|c|c|c|c|c|}
\hline \multirow[t]{3}{*}{ Catalysts } & \multirow[t]{3}{*}{$S_{\text {BET }}\left(\mathrm{m}^{2} \mathrm{~g}^{-1}\right)$} & \multirow[t]{3}{*}{ Composition $^{\mathrm{a}}$} & \multicolumn{3}{|l|}{$\mathrm{TPR}\left({ }^{\circ} \mathrm{C}\right)$} & \multirow{3}{*}{$\begin{array}{l}\text { CO oxidation } \\
T_{50}\left({ }^{\circ} \mathrm{C}\right)^{\mathrm{b}}\end{array}$} \\
\hline & & & \multirow[t]{2}{*}{$\mathrm{CeO}_{2}($ Surface $)$} & \multicolumn{2}{|c|}{$\mathrm{Co}_{3} \mathrm{O}_{4}$} & \\
\hline & & & & $\alpha$ & $\beta$ & \\
\hline $\mathrm{R} 230$ & 100 & $\mathrm{Co}_{3} \mathrm{O}_{4}$ & - & 280 & 390 & 98 \\
\hline $\mathrm{CeO}_{2}$ & 64 & $\mathrm{CeO}_{2}$ & 503 & - & - & - \\
\hline Ce20/R230-C350 & 60 & $\mathrm{CeO}_{2}, \mathrm{Co}_{3} \mathrm{O}_{4}$ & - & 312 & 375 & 112 \\
\hline Ce20/R230-C550 & 31 & $\mathrm{CeO}_{2}, \mathrm{Co}_{3} \mathrm{O}_{4}$ & - & 333 & 380 & 140 \\
\hline Ce20/R230-H200 & 109 & $\mathrm{CeO}_{2}, \mathrm{Co}_{3} \mathrm{O}_{4}, \mathrm{CoO}$ & - & 260 & 360 & 88 \\
\hline Ce20/R230-H400 & 40 & $\mathrm{CeO}_{2}, \mathrm{CoO}, \mathrm{Co}$ & - & - & 290 & 142 \\
\hline
\end{tabular}

${ }^{\mathrm{a}}$ Characterized from XRD data.

b Temperature for $50 \%$ CO conversion. 
due to the thermal treatment might be attributed to grain growth of the particles or collapse of pores [33]. The higher surface area for Ce20/R230-H200 (or Ce20/R230-C350) compared with that for Ce20/R230-H400 (or Ce20/R230-C550) can be understood from the pore size distribution and volume. The results are shown in Fig. 2. The pore size of R230 (Fig. 2(a)) distributes from 2 to $4 \mathrm{~nm}$ and from 5 to $18 \mathrm{~nm}$. The pore size of Ce20/R230-H200 (Fig. 2(d)) ranges from 2 to $15 \mathrm{~nm}$ and that of Ce20/R230-C350 (Fig. 2(b)) ranges from 5 to $20 \mathrm{~nm}$. The $\mathrm{Ce} 20 / \mathrm{R} 230-\mathrm{H} 200$ possesses larger pore volume than the $\mathrm{Ce} 20 /$ $\mathrm{R} 230-\mathrm{H} 400$. Also, the pore volume of Ce20/R230-C350 is larger than Ce20/R230-C550. The addition of ceria can promote the more uniform pore distribution. Apparently, pores in Ce20/R230-H400 and Ce20/R230-C550 have collapsed. The higher pore volumes of the composites are consistent with the higher surface areas. From the increasing of crystalline and decreasing of surface area of mixed oxides under hightemperature treating conditions, a possible explanation is the collapse of pores.

Fig. 3 shows the IR absorption spectra of ceria, cobaltic oxide and the $\mathrm{Ce} 20 / \mathrm{R} 230$ catalysts. All samples except $\mathrm{CeO}_{2}$ and Ce20/R230-H400 (Fig. 3(a) and (f)) show two distinct

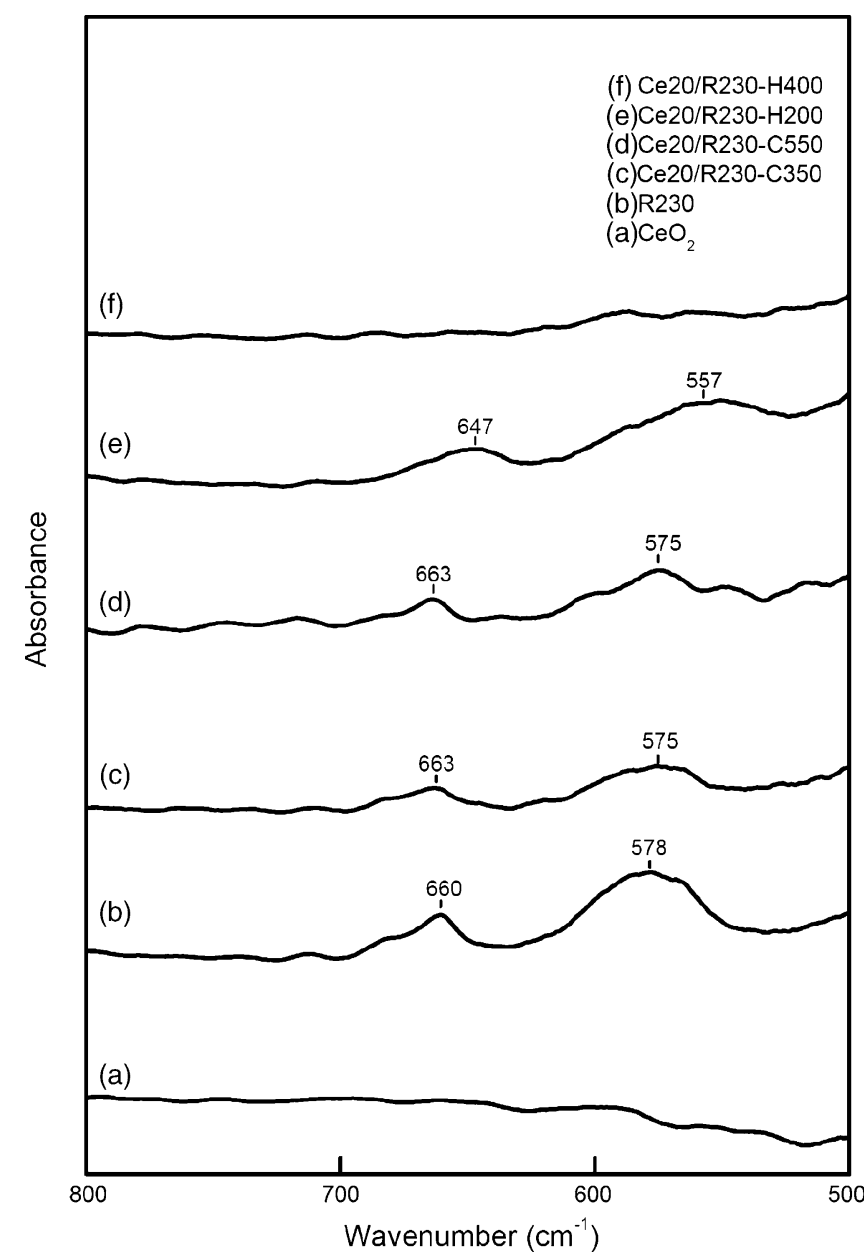

Fig. 3. IR characterization for ceria, cobaltic oxide and the Ce20/R230 catalysts: (a) $\mathrm{CeO}_{2}$; (b) $\mathrm{R} 230$; (c) Ce20/R230-C350; (d) Ce20/R230-C550; (e) Ce20/R230-H200; (f) Ce20/R230-H400. bands at 575-578 $\left(v_{1}\right)$ and $660-663\left(v_{2}\right) \mathrm{cm}^{-1}$ that are due to the stretching vibrations of the $\mathrm{Co}-\mathrm{O}$ bond of cobaltic oxide $[34,35]$. The $v_{1}$ band is characteristic of $\mathrm{OB}_{3}^{\mathrm{os}}$ (where $\mathrm{B}^{\mathrm{os}}$ denotes the $\mathrm{Co}^{3+}$ in octahedral holes) vibration and the $v_{2}$ band is attributed to the $\mathrm{A}^{\mathrm{ts}} \mathrm{B}^{\mathrm{os}} \mathrm{O}_{3}$ (where $\mathrm{A}^{\mathrm{ts}}$ denotes the $\mathrm{Co}^{2+}$ in tetrahedral holes) vibration in the spinel lattice [36,37]. At the same time, the two bands shift apparently to a lower wavenumber for Ce20/R230-H200 (Fig. 3(e)) due to the mixed phases [11] which indicate a larger number of defects at the surface of smaller nanoparticle (higher surface area) crystals to weaken the $\mathrm{Co}-\mathrm{O}$ bond strength. The displacement of the bands is in accordance with the structure of $\mathrm{CoO}_{x}$ (spinel for $\mathrm{Co}_{3} \mathrm{O}_{4}$ and face-centered cubic for $\mathrm{CoO}$ ).

The DRS spectral features are sensitive to nano-sized oxide particles [38]. The existence of $\mathrm{Co}_{3} \mathrm{O}_{4}$ is further confirmed by the DRS spectroscopy. The DRS spectra of ceria, cobaltic oxide and the Ce20/R230 catalysts are shown in Fig. 4. Both maxima characteristic bands at 720 and $420 \mathrm{~nm}$ (see Fig. 4(b)-(e)) are due to the formation of $\mathrm{Co}_{3} \mathrm{O}_{4}[39,40]$ where a migration to octahedral sites occurs. Herein it is worth noting that these bands become more intense as the surface area of catalyst increases. Pure $\mathrm{CeO}_{2}$ (Fig. 4(a)) shows a broad absorption feature with an

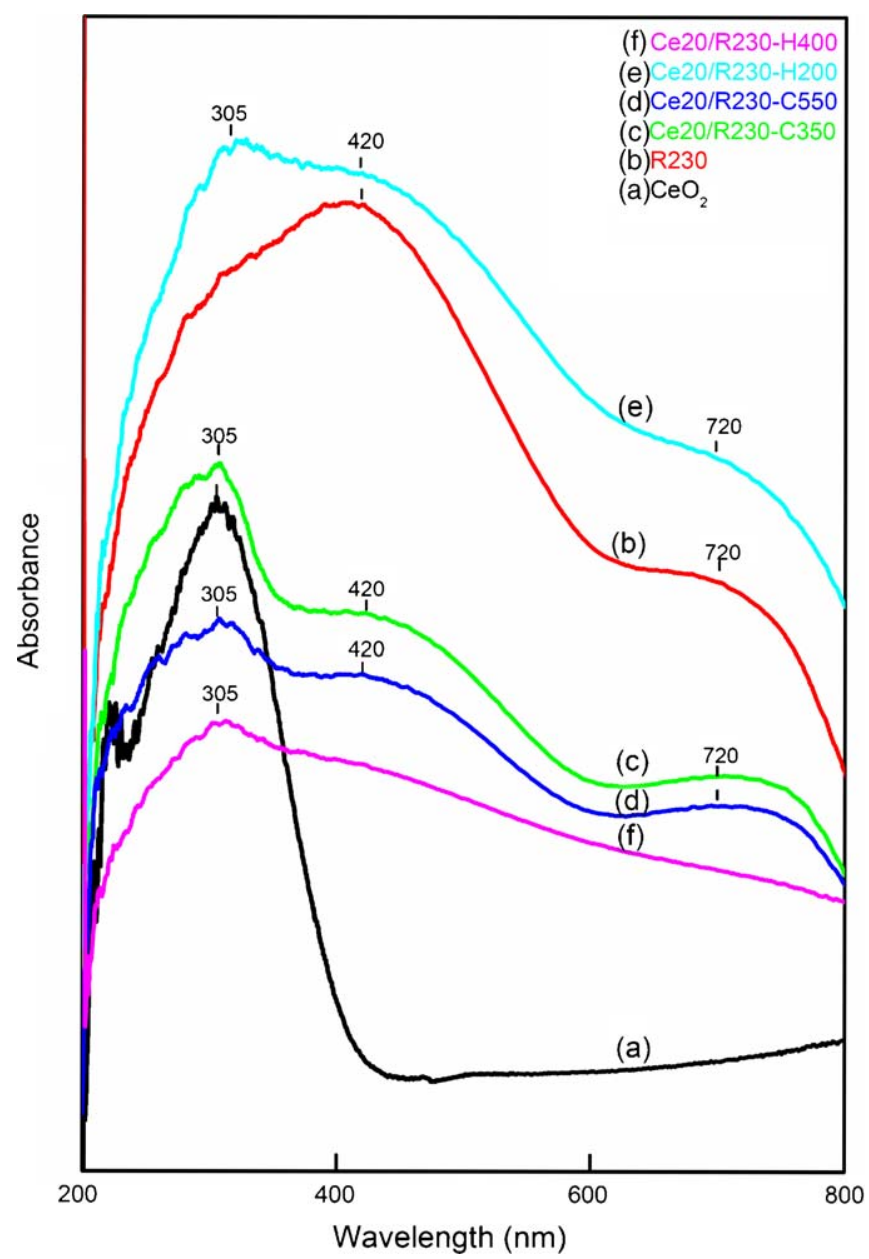

Fig. 4. The DRS spectra of ceria, cobaltic oxide and the Ce20/R230 catalysts: (a) $\mathrm{CeO}_{2}$; (b) $\mathrm{R} 230$; (c) Ce20/R230-C350; (d) Ce20/R230-C550; (e) Ce20/ R230-H200; (f) Ce20/R230-H400. 
absorption edge around $400 \mathrm{~nm}$ characteristic of the semiconducting nature $[41,42]$. The maximum characteristic band for pure $\mathrm{CeO}_{2}$ or $\mathrm{CeO}_{2} / \mathrm{Co}_{3} \mathrm{O}_{4}$ mixed oxides at $305 \mathrm{~nm}$ (see Fig. 4(a), (c)-(f)) corresponds to the localized $\mathrm{O} \rightarrow \mathrm{Ce}$ charge transfer transition involving a number of surface $\mathrm{Ce}^{4+}$ ions. Therefore the DRS results are in good agreement with XRD and IR analysis.

In order to understand the relationship of a $\mathrm{Co}-\mathrm{O}$ bond strength of Ce20/R230 catalysts, we further recognized with TPR technique to understand the reduction behavior of $\mathrm{CoO}_{x}$. Fig. 5 shows the TPR profiles for ceria, cobaltic oxide and the Ce20/R230 catalysts. All the samples except $\mathrm{CeO}_{2}$ and $\mathrm{Ce} 20 /$ R230-H400 (Fig. 5(a) and (g)) exhibit a similar TPR profile, consisting of two well-resolved reduction peaks (assigned as $\alpha$ peak and $\beta$-peak). These profiles point to a two-step reduction process: the first one ( $\alpha$-peak) of low intensity, starts at lowtemperature and overlaps with the more intense second one ( $\beta$-peak). According to the literature [10-12,30,43,44], the low-temperature $\alpha$-peak can be ascribed to the reduction of $\mathrm{Co}^{3+}$ ions, present in the spinel structure, into $\mathrm{Co}^{2+}$ (Eq. (1)), with the subsequent structural change to $\mathrm{CoO}$, which followed

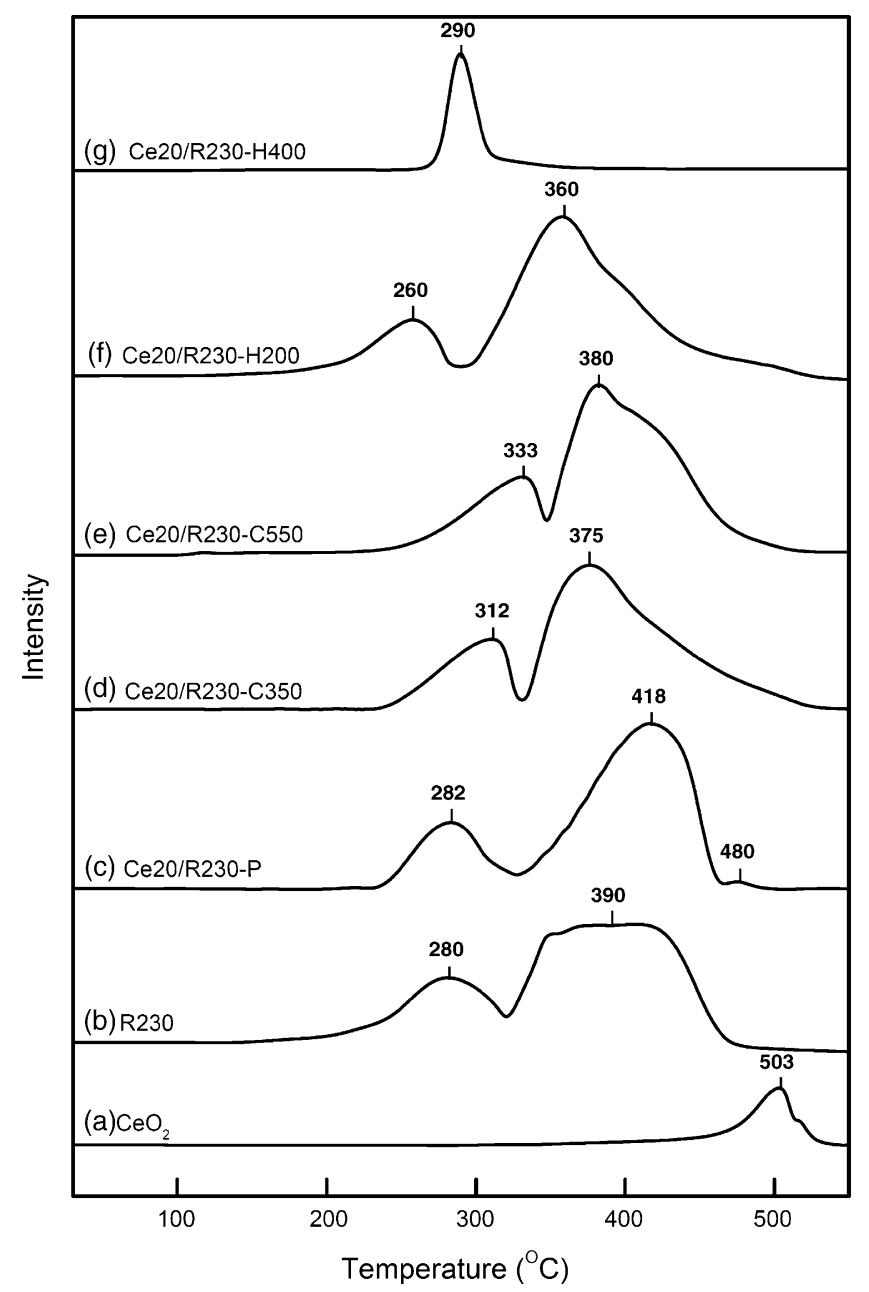

Fig. 5. TPR profiles for ceria, cobaltic oxide and the Ce20/R230 catalysts: (a) $\mathrm{CeO}_{2}$; (b) R230; (c) Ce20/R230-P; (d) Ce20/R230-C350; (e) Ce20/R230-C550; (f) Ce20/R230-H200; (g) Ce20/R230-H400. the higher temperature $\beta$-peak and is due to the reduction of $\mathrm{CoO}$ to metallic cobalt (Eq. (2)):

$$
\begin{aligned}
& \mathrm{Co}_{3} \mathrm{O}_{4}+\mathrm{H}_{2} \rightarrow 3 \mathrm{CoO}+\mathrm{H}_{2} \mathrm{O} \\
& \mathrm{CoO}+\mathrm{H}_{2} \rightarrow \mathrm{Co}+\mathrm{H}_{2} \mathrm{O}
\end{aligned}
$$

As can be seen in Fig. 5(b)-(f) and the fifth and sixth columns of Table 1, an apparent shift of the $\alpha$-peak and $\beta$-peak appears under different treatments which are related to the surface areas of composites. Compared to the $S_{\mathrm{BET}}$ (the second column of Table 1), both the $\alpha$-peak and $\beta$-peak shift to lower temperatures as the $S_{\mathrm{BET}}$ increases, i.e., the $\alpha$-peak and $\beta$-peak of Ce20/R230-H200 sample $\left(S_{\text {BET }}=109 \mathrm{~m}^{2} \mathrm{~g}^{-1}\right)$ are at 260 and $360{ }^{\circ} \mathrm{C}$ (Fig. 5(f)), respectively. While, the $\alpha$-peak and $\beta$ peak of Ce20/R230-C550 sample $\left(S_{\mathrm{BET}}=31 \mathrm{~m}^{2} \mathrm{~g}^{-1}\right)$ are at 333 and $380{ }^{\circ} \mathrm{C}$ (Fig. 5(e)), respectively. These results indicate that the increasing of $S_{\mathrm{BET}}$ of Ce20/R230 catalysts can weaken the bond strength of $\mathrm{Co}-\mathrm{O}$ and can promote more lattice oxygen desorption from $\mathrm{Co}_{3} \mathrm{O}_{4}$ to decrease the reduction temperature. Aside from the consecutive reduction of $\mathrm{Co}_{3} \mathrm{O}_{4}$, a reduction peak with lower intensity at $503{ }^{\circ} \mathrm{C}$ (Fig. 5(a)) is presented for pure $\mathrm{CeO}_{2}$. This peak is attributed to the removal of surface capping oxygen ions during the reduction reaction $[45,46]$. Moreover, the reduction behaviors of $\beta$-peak in $\mathrm{Ce} 20 / \mathrm{R} 230$ catalysts (Fig. 5(d)-(f)) and in pure $\mathrm{Co}_{3} \mathrm{O}_{4}$ (Fig. 5(b)) are somewhat different. The tailing $\beta$-peak in $\mathrm{Ce} 20 / \mathrm{R} 230$ catalysts is attributed to the spillover of hydrogen from $\mathrm{Co}_{3} \mathrm{O}_{4}$ to further reduce the capping oxygen of ceria, while the physically mixed sample [assigned as Ce20/R230-P and shown in Fig. 5(c)] does not show the tailing $\beta$-peak. According to the shift of reduction temperatures and tailing $\beta$-peak behavior, the combined effect between the $\mathrm{CeO}_{2}$ and $\mathrm{Co}_{3} \mathrm{O}_{4}$ is more evidence for the $\mathrm{Ce} 20$ / R230-H200 sample. Also, it is interesting to compare the reduction behavior of Ce20/R230-H400 and Ce20/R230-H200 catalysts. These are in agreement with the results of XRD analysis: different mixed phases obtained under reducing conditions give various diffraction patterns and reduction behavior. A consecutive reduction for $\mathrm{Co}_{3} \mathrm{O}_{4}$ species [that exist in $\mathrm{Ce} 20$ / R230-H200 sample, see Fig. 5(f) and Fig. 1(e)] and a single peak for $\mathrm{CoO}$ at $290{ }^{\circ} \mathrm{C}$ [that exist in Ce20/R230-H400 sample, see Fig. 5(g) and Fig. 1(f)] are observed separately. The pretreatment at $400{ }^{\circ} \mathrm{C}$ reduction has removed the capping oxygen of ceria, no tailing peak occurs in Ce20/R230-H400 sample.

\subsection{Catalytic activity}

In order to assess the catalytic activity of $\mathrm{CeO}_{2}$ on $\mathrm{CeO}_{2}$ / $\mathrm{Co}_{3} \mathrm{O}_{4}$ catalyst, we studied light-off curves for $\mathrm{CO}$ oxidation in a continuous flow micro-reactor. Fig. 6 presents the catalytic activities of ceria, cobaltic oxide and the Ce20/R230 catalysts as a function of reaction temperature. The catalytic activities of pure $\mathrm{CeO}_{2}$ and $\mathrm{Co}_{3} \mathrm{O}_{4}$ are also included for comparison. In the reaction temperature ranges (room temperature to $200{ }^{\circ} \mathrm{C}$ ), except for pure $\mathrm{CeO}_{2}$, the $\mathrm{CO}$ conversion over each sample generally increased with the reaction temperature. The activity of pure $\mathrm{CeO}_{2}$ is quite low at temperatures above $200{ }^{\circ} \mathrm{C}$, while the pure $\mathrm{Co}_{3} \mathrm{O}_{4}$ and $\mathrm{CeO}_{2} / \mathrm{Co}_{3} \mathrm{O}_{4}$ mixed oxides possess higher 


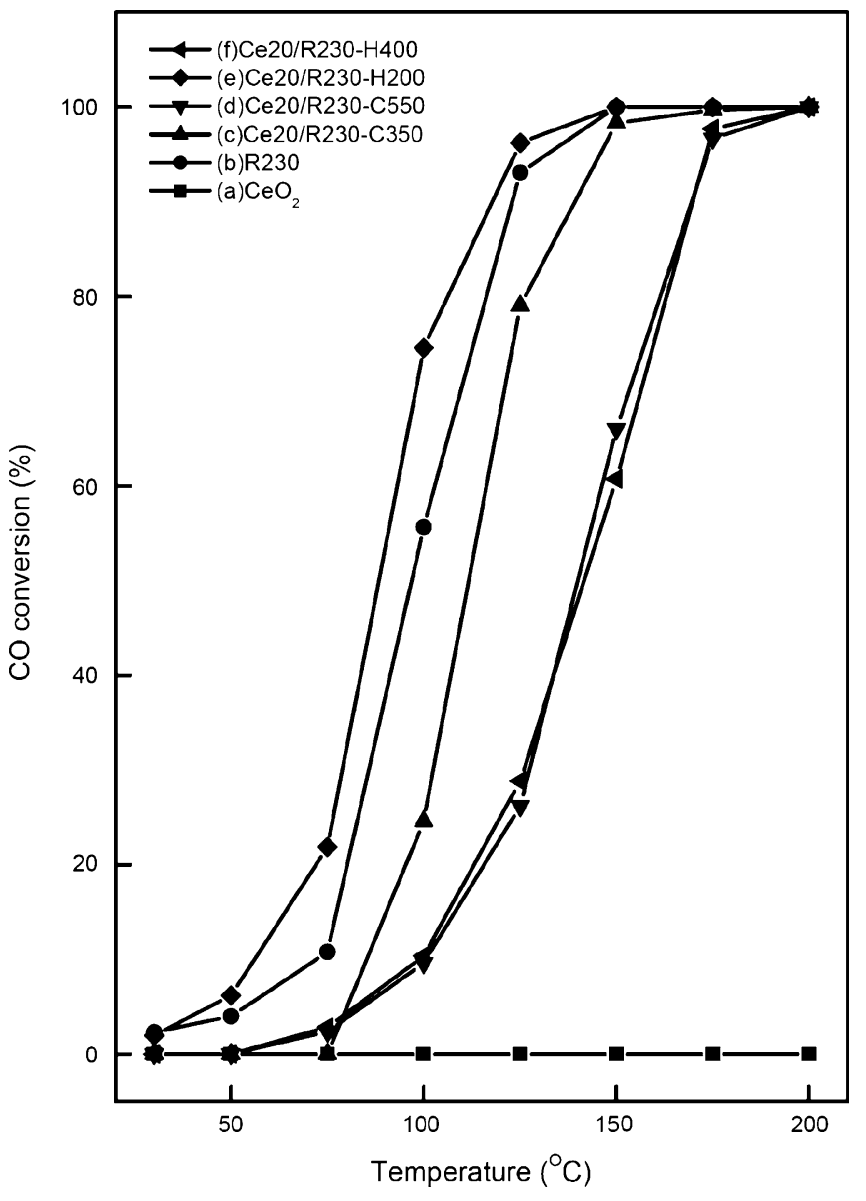

Fig. 6. Conversion profiles for $\mathrm{CO}$ oxidation over ceria, cobaltic oxide and the Ce20/R230 catalysts: (a) $\mathrm{CeO}_{2}$; (b) $\mathrm{R} 230$; (c) $\mathrm{Ce} 20 / \mathrm{R} 230-\mathrm{C} 350$; (d) $\mathrm{Ce} 20 /$ R230-C550; (e) Ce20/R230-H200; (f) Ce20/R230-H400.

activities than pure $\mathrm{CeO}_{2}$. A series of different thermal treatments procedure are used in the attempt to determine the optimum pretreatment condition for the catalysts. The $T_{50}$ (the conversion of $\mathrm{CO}$ reached $50 \%$ ) is chosen to judge the catalytic activity for each sample as shown in the last column of Table 1. Clearly, the activity toward $\mathrm{CO}$ oxidation is enhanced significantly by increasing the $S_{\mathrm{BET}}$ of catalyst. The higher the $\mathrm{S}_{\mathrm{BET}}$ of catalyst, the lower the $T_{50}$ value appears, meaning the higher activity.

Compared to the $S_{\mathrm{BET}}$ (the second column of Table 1) of catalysts, except for pure $\mathrm{CeO}_{2}$, the activity increases significantly by increasing the $S_{\mathrm{BET}}$, i.e., Ce20/R230-H200 $\left(T_{50}=88{ }^{\circ} \mathrm{C}\right.$ and $\left.S_{\mathrm{BET}}=109 \mathrm{~m}^{2} \mathrm{~g}^{-1}\right)>\mathrm{R} 230 \quad\left(T_{50}=98^{\circ} \mathrm{C}\right.$ and $\left.S_{\mathrm{BET}}=100 \mathrm{~m}^{2} \mathrm{~g}^{-1}\right)>\mathrm{Ce} 20 / \mathrm{R} 230-\mathrm{C} 350 \quad\left(T_{50}=112{ }^{\circ} \mathrm{C}\right.$ and $\left.S_{\mathrm{BET}}=60 \mathrm{~m}^{2} \mathrm{~g}^{-1}\right)>\mathrm{Ce} 20 / \mathrm{R} 230-\mathrm{C} 550\left(T_{50}=140^{\circ} \mathrm{C}\right.$ and $\left.S_{\mathrm{BET}}=31 \mathrm{~m}^{2} \mathrm{~g}^{-1}\right) \sim \mathrm{Ce} 20 / \mathrm{R} 230-\mathrm{H} 400 \quad\left(T_{50}=142^{\circ} \mathrm{C} \quad\right.$ and $\left.S_{\mathrm{BET}}=40 \mathrm{~m}^{2} \mathrm{~g}^{-1}\right)$. The best active sample (Ce20/R230$\mathrm{H} 200$ ) is achieved over the low-temperature reducing pretreatment (reduction under $200{ }^{\circ} \mathrm{C}$ ), where $T_{50}$ is reached at temperatures as low as $90{ }^{\circ} \mathrm{C}$ and $100 \% \mathrm{CO}$ conversion is reached at about $150{ }^{\circ} \mathrm{C}$. Notice that the $T_{50}$ for the least active sample (Ce20/R230-H400) is achieved over the high-temperature reducing pretreatment (reduction under $400{ }^{\circ} \mathrm{C}$ ) that reaches around $142{ }^{\circ} \mathrm{C}$ and $100 \% \mathrm{CO}$ conversion is reached at about $200{ }^{\circ} \mathrm{C}$. The increase in $T_{50}$ for the Ce20/R230-H400 may mean that cobalt metal covering the surface of $\mathrm{CoO}$ decreases the $S_{\mathrm{BET}}$ to depress the CO oxidation activity. Also, in the calcined pretreatment, the low-temperature treating condition can get higher activity.

On the basis of the above results, we suggest that the catalytic activity of $\mathrm{Ce} 20 / \mathrm{R} 230$ catalysts is closely related to their surface area. Increasing of the $S_{\mathrm{BET}}$ of $\mathrm{CeO}_{2} / \mathrm{Co}_{3} \mathrm{O}_{4}$ catalysts weakens the $\mathrm{Co}-\mathrm{O}$ bond strength and promotes more lattice oxygen desorbed from $\mathrm{Co}_{3} \mathrm{O}_{4}$ to increase the $\mathrm{CO}$ oxidation activity. In summary, the addition of $\mathrm{CeO}_{2}$ into $\mathrm{Co}_{3} \mathrm{O}_{4}$ can sustain a high catalytic activity as long as an optimized pretreatment will maintain high surface area.

\section{Conclusion}

$\mathrm{CeO}_{2} / \mathrm{Co}_{3} \mathrm{O}_{4}$ catalysts of different pretreatment conditions have been characterized and tested for $\mathrm{CO}$ oxidation. The following conclusions are drawn:

(1) Addition of ceria shows good resistance to the sintering of cobaltic oxide under high-temperature due to the combined effects of cobaltic oxide and ceria.

(2) It is necessary to prepare $\mathrm{CeO}_{2} / \mathrm{Co}_{3} \mathrm{O}_{4}$ catalysts with larger surface area for a good catalytic performance.

(3) The optimized pretreatment under low-temperature is more suitable to prepare $\mathrm{CeO}_{2} / \mathrm{Co}_{3} \mathrm{O}_{4}$ catalysts for $\mathrm{CO}$ abatement application.

(4) The most active sample is Ce20/R230-H200. The $T_{50}$ for $\mathrm{CO}$ oxidation is $88^{\circ} \mathrm{C}$.

\section{Acknowledgement}

We are pleased to acknowledge the financial support for this study by the National Science Council of the Republic of China under contract number NSC 93-2113-M-014-003.

\section{References}

[1] D.R. Schryer, B.T. Upchurch, B.D. Sidney, K.G. Bromn, G.B. Hoflund, P.K. Herz, J. Catal. 130 (1991) 314.

[2] Y. Kim, S.K. Shi, J.H. White, J. Catal. 61 (1980) 61.

[3] Y.Y. Yao, J. Catal. 89 (1984) 152.

[4] M. Olsbye, R. Wendelbo, T. Akporiayc, Appl. Catal. A152 (1997) 127.

[5] M. Okumura, N. Masuyama, E. Konishi, S. Ichikawa, T. Akita, J. Catal. 208 (2002) 485.

[6] G. Avgouropoulos, T. Ioannides, Ch. Papadopoulou, J. Batista, S. Hocevar, H.K. Matralis, Catal. Today 75 (2002) 157.

[7] F. Severino, J. Laine, Ind. Eng. Chem. Prod. Res. Dev. 22 (1983) 396.

[8] J. Jansson, J. Catal. 194 (2000) 55.

[9] J. Jansson, A.E.C. Palmqvist, E. Fridell, M. Skoglundh, L.O. Sterlund, P. Thormahlen, V. Langer, J. Catal. 211 (2002) 387.

[10] H.K. Lin, C.B. Wang, H.C. Chiu, S.H. Chien, Catal. Lett. 86 (2003) 63.

[11] H.K. Lin, H.C. Chiu, H.C. Tsai, S.H. Chien, C.B. Wang, Catal. Lett. 88 (2003) 169.

[12] C.B. Wang, C.W. Tang, S.J. Gau, S.H. Chien, Catal. Lett. 101 (2005) 59.

[13] P. Broqvist, I. Panas, H. Person, J. Catal. 210 (2002) 198.

[14] B.A. Sazonov, V.V. Popovskii, G.K. Boreskov, Kinet. Catal. 9 (1968) 255.

[15] M. Haneda, Y. Kintaichi, N. Bion, H. Hamada, Appl. Catal. B46 (2003) 473. 
[16] D.S. Lafyatis, G.P. Ansell, S.C. Bennett, J.C. Frost, P.J. Millington, R.R. Rajaram, A.P. Walker, T.H. Ballinger, Appl. Catal. B 18 (1998) 123.

[17] A. Martinez-Arias, M. Fernandez-Garcia, O. Galvez, J.M. Coronado, J.A. Anderson, J.C. Conesa, J. Soria, G. Munuera, J. Catal. 195 (2000) 207.

[18] A. Martinez-Arias, R. Cataluna, J.C. Conesa, J. Soria, J. Phys. Chem. B102 (1998) 809.

[19] C. Serre, F. Garin, G. Belot, G. Maire, J. Catal. 141 (1993) 1.

[20] S.H. Oh, J. Catal. 124 (1990) 477.

[21] C. Serre, F. Garin, G. Belot, G. Maire, J. Catal. 141 (1993) 9.

[22] H.C. Yao, Y.F.Y. Yao, J. Catal. 86 (1984) 254.

[23] J.X. Yuana, L.G. Glieb, Z.R. Xiana, M.J. Xina, C. Yua, Z.X. Ming, Appl. Surf. Sci. 173 (2001) 208.

[24] A. Trovarelli, Catal. Rev. Sci. Eng. 38 (1996) 439.

[25] J.C. Summers, S.A. Ausen, J. Catal. 58 (1979) 131.

[26] W. Liu, F.S. Maria, J. Catal. 153 (1995) 304.

[27] A. Trovarelli, Catal. Rev. 38 (1996) 439.

[28] M.F. Luo, Y.J. Zhong, X.X. Yuan, X.M. Zheng, Appl. Catal. A162 (1997) 121.

[29] A. Martinez-Arias, M. Fernandez-Garcia, J. Soria, J.C. Conesa, J. Catal. 182 (1999) 367.

[30] M. Kang, M.W. Song, C.H. Lee, Appl. Catal. A251 (2003) 143.

[31] U. Oran, D. Uner, Appl. Catal. B 54 (2004) 183.
[32] M.A. Centeno, C. Portales, I. Carrizosa, J.A. Odriozola, Catal. Lett. 102 (2005) 289.

[33] G.A. El-Shobaky, N.M. Deraz, Mater. Lett. 47 (2001) 231.

[34] C. Spenser, D. Schroeder, Phys. Rev. B9 (1974) 3658.

[35] T. Andrushkevich, G. Boreskov, V. Popovskii, L. Pliasova, L. Karakchiev, A. Ostankovitch, Kinet. Catal. 6 (1968) 1244.

[36] St.G. Christoskova, M. Stoyanova, M. Georgieva, D. Mehandjiev, Mater. Chem. Phys. 60 (1999) 39.

[37] R.N. Singh, J.P. Pandey, N.K. Singh, B. Lal, P. Chartier, J.F. Koenig, Electrochim. Acta 45 (2000) 1911.

[38] B.M. Weckhuysen, R.A. Schoonheydt, Catal. Today 49 (1999) 441.

[39] M. Lojacono, A. Cimino, G.C.A. Schuit, Gazz. Chim. Ital. 103 (1973) 1281.

[40] F.J. Gillambias, A.L. Agudo, V. Rives-Arnau, J. Mater. Sci. 17 (1982) 936.

[41] S.P. Tandon, J.P. Gupta, Phys. Status Solidi 38 (1970) 363.

[42] A. Bensalem, F.B. Verduraz, M. Delamar, G. Bugli, Appl. Catal. A121 (1995) 81.

[43] P. Arnoldy, J.A. Moulijn, J. Catal. 93 (1985) 38.

[44] M. Voß, D. Borgmann, G. Wedler, J. Catal. 212 (2002) 10.

[45] G.R. Rao, H.R. Sahu, B.G. Mishra, Colloids Surf. A220 (2003) 261.

[46] X.C. Zheng, S.P. Wang, X.Y. Wang, S.R. Wang, X.G. Wang, S.H. Wu, Mater. Lett. 59 (2005) 2769. 